\section{ASESINAS POR PASIÓN: infanticidas en Río de Janeiro, 1841-1936}

Assassins for Passion: Infanticides in Rio de Janeiro, 1841-1936
Jhoana

\section{PRADA MERCHÁN}

(1) jh.pramer@gmail.com

Universidade Federal

do Rio de Janeiro

Rio de Janeiro, RJ, Brasil

\section{RESUMEN}

Los discursos higienistas surgidos a partir de la segunda mitad del siglo XIX se enfocaron en dar una renovada visión a temas como el matrimonio, maternidad y locura puerperal, cuestiones que fueron al mismo tiempo relacionadas con la concepción del crimen femenino. En especial, los infanticidios crearon preocupación entre los médicos, generando debates y controversias al momento de ser analizados, llegando al punto de que éstos se adueñaron de esos discursos, no sólo para tratarlos como un hecho físico-patológico, sino también como una contrariedad de carácter moral que surgía en las madres, pero mucho más en aquellas consideradas desviantes y fuera del patrón normal como las infanticidas. Por esta razón, resultó complejo percibir jurídica, médica y moralmente a una madre asesina, mucho más cuando algunas alegaban pérdida total de sus sentidos y con ello consiguieron la benevolencia de la justicia. En consecuencia, este artículo aborda a través de una perspectiva histórico-social casos de infanticidio ocurridos en Río de Janeiro entre 1841 y 1936 . Esta observación se fundamenta en el análisis de las particularidades y procedimientos llevados en los procesos criminales abiertos durante este periodo por infanticidio en la ciudad y que reposan en el Archivo Nacional de Brasil.

Palavras-chave: infanticidio, honor, violencia, Rio de Janeiro, Siglos XIX-XX.

\begin{abstract}
The hygienist speeches that emerged from the second half of the nineteenth century were focused on giving a renewed vision to issues such as marriage, motherhood and puerperal madness, issues that were at the same time related to the conception of female crime. In particular, infanticides created concern among physicians, generating debates and controversies during their analysis, reaching the point that they adopted these discourses, not only to treat them as a physicopathological fact, but also as a moral character overturn that arose in mothers, but much more in those considered deviants and outside the normal pattern, as the infanticides. For this reason, it was complex to perceive a murderous mother in legal, medical and moral terms, particularly when some of them alleged total loss of their senses and thereby achieved the benevolence of justice. Consequently, this article addresses, through a historical-social perspective, cases of infanticide that occurred in Rio de Janeiro between 1841 and 1936. This observation is based on the analysis of the particularities and procedures carried out in the criminal proceedings opened during this period for infanticide in the city that rest in the National Archive of Brazil.
\end{abstract}

Keywords: infanticide, honor, violence, Rio de Janeiro, $19^{\text {th }}$ and $20^{\text {th }}$ century. 
L os infanticidios son crímenes excepcionales y ambivalentes. Fueron precisamente estas características las que hicieron que comenzasen a generar interés y debates acalorados a partir de la segunda mitad del siglo XIX y sobre todo durante las primeras décadas del $\mathrm{XX}$ por parte de médicos y juristas que comenzaron a discutir sus causas y motivaciones, pero mucho más su penalidad. Este último punto, fue realmente controvertido, estando en varios momentos en completo desacuerdo tales especialistas. El auge y la injerencia que la medicina ejerció en tales procesos se determinó como consecuencia del auge de las teorías degenerativas sobre el crimen, en donde las infanticidas surgieron como madres que podían asesinar a sus hijos llevadas por un sentimiento de excesiva pasión. Para tal aseveración, también contribuyeron los discursos higienistas de principios del siglo XX que pretendían "normalizar" e "higienizar" la sociedad, una sociedad que enfrentaba los peligros de la modernidad. Estos discursos no significaron más que la intervención de los médicos en situaciones tan privadas como el matrimonio y el sexo entre parejas. Para los galenos, el cuerpo femenino se convirtió en un ente inestable que necesitaba de estudio y regulación, en este sentido, la maternidad y el sentimiento maternal, así como la lactancia pasaron a ser puntos transcendentales de ese control.

La mujer se convierte así, a partir de este momento en foco de higiene; su desarrollo, vivencia e incluso sentimientos fueron encaminados como una cuestión natural basada en la misión maternal como única vía de su realización personal y social. La feminidad se relacionó con el hecho biológico de ser madres, y no cualquier madre, sino con una madre amorosa que amamantaba. Por esta razón, las que no encajaban dentro de este papel, las que no lo ejercían, eran tratadas como antinaturales, locas, histéricas, y alienadas, mucho más, aquellas que asesinaban a sus hijos acabados de nacer. Las infanticidas generaban tanto horror porque resultaba difícil tanto para médicos como para juristas explicar su existencia, contravenciones que se extrapolaron a los debates en la justicia donde resultó igualmente complejo y contradictorio juzgarlas.

Atendiendo a esto, este artículo aborda las particularidades y los procedimientos llevados en los casos de infanticidio cometidos en la ciudad de Río de Janeiro entre 1841 y 1936, siendo que, el recorte de estos años viene dado en función del primer caso hallado en el siglo XIX y el último antes de la promulgación del Código Penal de 1940. La tarea de investigar casos de este tipo, sólo puede ser hecha por medio de una valiosísima fuente histórica: los procesos criminales. Por esta razón, para este estudio, fueron tomados todos los 31 casos hallados y tipificados como infanticidios, seleccionados a partir de las Pretorias Criminales de Río de Janeiro que aglomeraban las Feligresías que dividían la ciudad durante la fase analizada. Estos casos están separados en 15 inquiridos que representan investigaciones preliminares y 16 procesos que contienen todos los pasos de la indagación, incluso las sentencias y que reposan tanto en el Aquivo Nacional como en el Museu do Tribunal da Justiça do Rio de Janeiro. Consecuentemente, con la intención de enriquecer la investigación, se sumaron 32 inquéritos sobre aborto comprendidos entre 1904 y 1938 y 41 casos sobre aparecimiento de feto, mortinatos, recién nacidos y abandono acaecidos entre 1900 y 1933. 


\section{Infanticidio, un crimen por honor}

Es imposible hablar de infanticidio sin abordar el honor. Este crimen ha causado a lo largo de la historia contradicciones, repudio y aversión, precisamente porque se trata de un delito cometido en contra de un ser acabado de nacer o de pocos días de existencia con la especial característica de que es su propia madre, quien cegada ante un sentimiento de desesperanza y rechazo social suprime su vida. Para que se tipifique un delito como un infanticidio, la muerte de ese recién nacido debe ser ocasionada de forma especial por su propia madre o los ascendentes maternos con la intención de ocultar la deshonra.

La muerte de la criatura debe ser llevada a efecto por medio de actos positivos o negativos por la madre que ha sido ilegítimamente fecundada con la finalidad de salvaguardar su propio honor o de evitar eminentes sevicias, por tanto, el infanticidio se enmarca como el asesinato que se ocasiona a cualquier infante dentro de un plazo determinado (a veces indeterminado) cuando se trata de la influencia del estado puerperal, variando así en cada parturienta (OSORIO, 1981, p. 378). El infanticidio puede ser cometido durante el nacimiento de la criatura o cuando la madre se encuentra bajo la influencia del estado puerperal "la acción, consiste en matar a un ser humano que ha comenzado a nacer o después de nacido por un término de tiempo que está referido, no a condiciones del niño, sino a la situación de la madre, que ha de encontrase bajo la influencia del estado puerperal" (GARCÍA MAAÑON, 1990, p. 37). La acción se comete, justamente, por no ser el niño un fruto legítimo, ya que la vergüenza social que conlleva esa ilegitimidad, la alta valoración que se ha impuesto a la procreación, el embarazo, el parto y la existencia de un hijo en esas condiciones lesionan el aspecto externo de la reputación y consideración social de la madre quien enfrenta una situación que no puede controlar y por esa razón es el temor a esas consecuencias funestas, creadas precisamente por la intolerancia de la sociedad, las que llevan a la infanticida a destruir la existencia material del nuevo ser (FÉBRES CORDERO, 1962, p. 50).

Para que el asesinato de una criatura sea encuadrado como un infanticidio deben estar presentes en el delito tres condiciones específicas: el tiempo, la calidad de las personas y el móvil, siendo la primera de ellas de carácter material y las segundas de carácter moral. El sujeto pasivo en el infanticidio debe ser un niño recién nacido (tiempo) que haya nacido vivo, decretando el término recién nacido que el ser ha salido del claustro materno con vida, por ello, se requiere que tenga una vida concreta y cierta, y no solamente una esperanza de vida como sucede en el caso del aborto. La frase, recién nacido, indica que no es suficiente que el niño haya comenzado a desprenderse del claustro materno, sino que debe haber concluido el parto. Se requiere de una vida independiente desprendida por completo de la respiración placentaria, poseyendo así, una respiración pulmonar.

El elemento más importante dentro del infanticidio, consiste en el motivo de salvar el honor. En ese sentido, es preciso definir qué entiende por honra la legislación; es la observancia de determinadas disciplinas de carácter moral, que forman la honra 
sexual, siendo esta la que se protege. Concierne a la mujer casta, aquella que ha perdido su pureza, que ha cometido un pecado amoroso, con relaciones sexuales ilícitas, que al encubrir su falta pretende seguir conservando su imagen pública, que en este caso sería la base de todas las virtudes femeninas, sobre todo la de una honrada reputación. La honra en el infanticidio no es más que "la honra sexual, una honra especial que se refiere al crédito que pueda gozar una mujer dentro del medio social en que se desenvuelve" (GARCÍA MAAÑON, 1990, p. 81).

La ley se refiere al honor externo y no al honor interno, o sea a la propia situación de la persona. Se trata del crédito de que goza la mujer desde el punto de vista sexual, porque ante sí misma, aunque pueda tener que reprocharse, nada tiene que defender o proteger. El honor que se trata de salvar es el honor social, pues sea cual sea la opinión que de éste se tenga, es una realidad que el amor natural, adúltero o extra-matrimonial tiene en su contra cierta forma de denigración y desprecio social, que algunas veces es capaz de llegar a los más inhumanos castigos por lo que resulta apreciable que es el temor a este tipo de sanciones derivadas del deshonor, lo que dan lugar a la atenuante del delito (FÉBRES CORDERO, 1962, p. 109).

Es por esas razones que los motivos que conducen a una madre a matar a su hijo comienzan con la actitud de un acto carnal clandestino, y ocultar por nueve meses el embarazo, haciendo eclosión la angustia en el momento del parto cuando el grito de la criatura señala inevitablemente la deshonra que con tanto cuidado ha escondido. Es en ese instante de confusión y descontrol con la emotividad a flor de piel cuando decide deshacerse del producto de su concepción; es aquí donde la causa emotiva sirve de consideración atenuante (MENDOZA TROCONIS, 1948, p. 149). Son los factores subjetivos los cuales actúan en la mente de la madre y en estado consiente y deliberante la que la impulsan a realizar un hecho repugnante a su maternidad. Estos factores son el producto de las circunstancias, reunidas en su perjuicio y en contra del deseo y de la necesidad para su existencia personal: mantener el concepto de buena fama y de mujer honrada que hasta entonces cree merecer ante el medio ambiente de su familia y de sus actividades. La intención de ocultar la deshonra dentro del delito de infanticidio tiene una enorme relevancia; tanta que, en la mayoría de las legislaciones ${ }^{1}$, la pena es muy inferior a la del homicidio-filicidio, pues se entiende que la autora o autores del delito se han sentido presionados por la vergüenza social que provoca la maternidad de la mujer soltera.

\section{Honor: una concepción variable}

La noción de honor ha variado de acuerdo a los contextos históricos, culturales y sociales de cada sociedad, por lo que resulta impreciso otorgar una definición única y universal del término. A pesar de ello, se pueden encontrar importantes coincidencias entre unas y otras determinaciones sobre el honor, éste forma parte de la ética del individuo, quien se contempla a sí mismo a través de los demás. Éste se relaciona con la reputación, la respetabilidad o la gloria, valores que se obtiene por medio del juicio de terceros dentro de los cuales se pretende ejercer una posición superior, pues se establece una lucha de poder mientras se cuestiona sí los demás son merecedores 
de la misma integridad. Precisamente, la pérdida del honor constituye un conflicto entre lo privado y lo público, en donde la mujer forma parte de lo primero y el hombre de lo segundo. El honor pertenece y se maneja en el dominio de lo privado, ya sea internamente en el individuo, de su casa y familia, pero se pone en evidencia en lo público.

En este sentido, el honor no solamente se circunscribía a la herencia de la pureza racial, sino que representaba en muchos casos la historia de una buena familia que se basaba en generaciones de matrimonios dignos e hijos legítimos. En la sociedad colonial el honor familiar dependió en gran medida del recato de sus mujeres, por lo que la estricta vigilancia de las mimas se convertía en algo necesario que a la larga permitía evitar la deshonra ante una posible conducta inmoral femenina. Ese honor estaba vinculado enormemente con el comportamiento de las mujeres, pero en especial a su sexualidad, por ello se le imponían cargas y restricciones a la hora de entablar cualquier tipo de relación con el sexo opuesto, se esperaba que ellas fueran prudentes para no provocar tentaciones en los hombres, asimismo se dio gran importancia a la iniciación sexual de las jóvenes, entendiendo que ésta sólo debía ocurrir dentro del matrimonio y sí sucedía lo contrario ellas estaban expuestas a ser condenadas socialmente no sólo por su deshonra, sino por la de su familia también (RAMÍREZ, 2005, p. 54). Lo que se trataba de evitar era la concepción de hijos ilegítimos que ante su condición estarían muertos socialmente, sin esperanzas de ascensos y oportunidades.

En las dimensiones públicas y privadas que supuso el honor, en el caso de los hombres (lo público) se manifestaba en el valor moral del individuo y en la reputación, elemento que otorgaba significado a la masculinidad y en el caso de las mujeres el honor se basaba en su conducta y sexualidad. Esa dimensión pública del honor se manifestó ante el status y el prestigio social, por ello la protección de la reputación estuvo ligada a la reputación sexual femenina, reputación que cuidaba el honor de una familia, incluso el de una sociedad. Precisamente, el honor femenino se sustentó y encontró su base en tres condiciones ideales: a) el matrimonio, que funcionaría como pilar fundamental de la sociedad donde se enmarcarían las acciones correctamente vistas ante los ojos de los demás y dónde la familia que se conforma por medio de él, recibiría el respeto y reconocimiento social de ser legítima ante todos sus efectos; b) la sexualidad que sólo estaría permitida dentro de la institución matrimonial y con fines reproductivos, y por último c) la legitimidad que se expresaba por medio de la herencia transmitida de generación en generación para perpetuar el patrimonio familiar y que gozaba por medio del matrimonio de total legalidad.

Por su parte, la concepción de honra en la sociedad carioca mantuvo casi invariablemente las mismas características de otras ciudades coloniales de América Latina; la supra-valoración de la virginidad como máxima representación de la honra femenina: "fuese en relación a las parejas específicas o a la sociedad como un todo, la honra sexual era frecuentemente usada para consolidar jerarquías basadas no solamente en las relaciones de género, como también en las de raza y clase" (CAULFIELD, 2000, p. 26). Parece que esa diferencia de raza y clase fue mucho más 
marcada en Río de Janeiro, debido a la presencia de mayor componente de esclavos o esclavos libertos afrodescendientes. Por esta razón, y como han demostrado algunos estudios, entre ellos el de Ann Twinam (2009, p.61), las nociones europeas de honra sexual se adaptaron al contexto de cada sociedad. Por ejemplo, no es de olvidar que Brasil ganó la reputación a nivel europeo de "tierra de demonios y tentaciones que estimulaban la sensualidad y propagaban la inmoralidad”. Ante ello, las clases privilegiadas dieron un inmenso valor a la castidad de las mujeres, pero especialmente, a las suyas, quienes para lograr la superioridad moral necesitaban de excesiva vigilancia y clausura.

Con esto, resulta indudable que la concepción de honra femenina varió de acuerdo al lugar y al tiempo. Esta situación queda clara cuando se comienzan a generar discusiones sobre la preocupación del término honra durante los gobiernos liberales en función de la construcción de la Patria-Nación y en la modernización y moralización de los lugares públicos y privados; por tanto, se hace más demarcado el papel de cada espacio distanciándose y delimitándose entre sí. De este modo, la mujer se comenzó a entender como reproductora de generaciones civilizadas útiles al progreso; surge el ideal de madre-educadora, trasmisora de moral, el llamado ángel del hogar a quienes se les restringió sus dominios a la casa y a la protección de la familia.

Contradicciones estaban a la orden de tales discusiones, la calle, por ejemplo, fue sinónimo de desvío y tentaciones, debiendo, especialmente las madres pobres, ejercer mayor vigilancia sobre sus hijas. Este tipo de exigencia, era una situación casi imposible de cumplir, ya que muchas necesitaban trabajar y con eso salían solas y frecuentaban espacios públicos en busca de sus ganancias (SOIHET, 2015, p. 365). Este tipo de mujer pobre que trabajaba, amenazaba a nivel simbólico la familia, porque la misma no se sometía al control masculino del marido; ella en sí misma representaba una enfermedad por no ejercer su papel de esposa y madre que era fundamental para el sostenimiento de la vida conyugal (ENGEL, 2004, p. 79).

Tales valores basados en un tipo de honra que tomaba como base una noción bien tradicional y que fue heredada del periodo colonial tuvo una permanencia enorme a través del siglo XIX y principios del XX, tanto así, que la concepción tradicional del honor siguió discutiéndose como válida dentro de una sociedad que clamaba ser civilizada e higiénica. Justamente, los juristas y médicos durante esta época no dudaron en colocar en debate la concepción de honra, sobre todo cuando definían y juzgaban delitos contra o por honor. De esta manera, el Código Criminal de 1830 conservó en su texto concepciones tradicionales sobre el honor y la moralidad en defensa de la familia. Asimismo, el Código Penal de 1890, a pesar de los esfuerzos de la escuela positiva del derecho, siguió los modelos clásicos y tradicionales sobre la honra femenina y aunque este código provocó infinidad de divergencias, tuvo una validez de cincuenta años cuando fue sustituido en 1940. Tal divergencia surgía básicamente entre una defensa por la honra fisiológica y una honra moral: "Las ofensas a la honra sexual de las mujeres eran más complejas: ellas podían ofender la autoridad moral de la Iglesia y del Estado, la autoridad paterna privada, la integridad individual o el patrimonio familiar" (CAULFIELD, 2000, p. 59). 


\section{Mujer: criminal en potencia}

A mediados del siglo XIX, muchos especialistas comenzaron a preocuparse por cómo entender el crimen. A partir de ese momento, se instauró la teoría de la "degeneración" que lo entendió como el resultado de un psiquismo, de una perturbación mental que finalmente condujo al entendimiento del mismo como fruto de una naturaleza individual. El crimen comenzó a juzgarse como producto de una enfermedad y como un atributo personal. Así, se relacionaron los comportamientos delictivos a un cierto biodeterminismo realzado por las teorías de la Escuela Positiva o Escuela Antropológica del Derecho.

En este sentido, especialmente, el crimen femenino se concibió como una patologización de su comportamiento, donde al mismo tiempo se comienzan a explicar las diferencias entre los hombres y las mujeres con base en sus órganos sexuales. En función de esto, se comprendió a la mujer como un ser dominado por sus órganos de reproducción sexual: los ovarios y el útero. Precisamente, a partir del siglo XIX, gracias al campo de la ginecología, se estableció un vínculo entre los disturbios ginecológicos con los mentales. Esta idea también se hizo presente en el campo psiquiátrico, que estipuló definiciones sobre el comportamiento patológico femenino como causa fisiológica y anatómica de las mujeres. Especialmente, en Brasil, ciertos especialistas de la medicina y del derecho, comprendieron la delincuencia como el resultado de "determinaciones psico-biológicas", basándose en la idea de que el crimen era producto de una enfermedad cuyo principio se encontraba en la "degeneración" de los individuos. Pensaban de este modo, que esa "degeneración" creadora de "anomalías orgánicas", sería el resultado tanto de la transmisión de caracteres hereditarios, como de la adquisición de elementos del medio ambiente (RINALDI, 2015, p.51).

De esta forma, se construyó una clasificación de los tipos de criminales basadas en las teorías del criminólogo italiano y fundador de la Escuela Positiva Enrico Ferri. De acuerdo con este autor, los criminales podían ser divididos en tres tipos: a) "criminales natos", "criminales locos" y "criminales ocasionales", donde se incluían individuos con tendencias hereditarias al crimen, pero que podían manifestarlas esporádicamente; b) "criminales por hábito" que eran consecuencia del medio social y c) "criminales por pasión". Especialmente, los llamados "criminales por pasión".

Justamente, los crímenes cometidos tanto por honor como por "pasión" eran encuadrados en la categoría de "crímenes pasionales". Los juristas y médicos-legalistas pensaban que la "pasión" y la noción de honor ultrajada podían producir un estado transitorio de perturbación de los sentidos, sin demostrar cualquier tipo de síntoma que fuese apreciable superficialmente. Ante este tipo de delitos y criminales, se experimentaba una cierta condescendencia al momento de ser juzgados. Este tipo de benevolencia, se basaba en una moralidad tradicionalista fundamentada en la idea de que un hombre mantenía su honor intacto por medio de su conducta y la de sus familiares, especialmente la de una honra femenina sexual. Los juristas compartían la idea de que un hombre cuando veía perdida su honra sería invadido por un tipo de sentimiento que cegaba momentáneamente su razón, haciendo con que se valiese de 
todos los medios sociales posibles para rescatarla. En este caso, se puede plantear, que ese tipo de sentimiento funcionaba tanto para el rescate del honor masculino (muerte, duelo y matrimonio) así como para la defensa de la honra sexual femenina (matrimonio y crimen).

Ciertamente, siendo las mujeres quienes especialmente estaban sujetas al mundo de lo privado-doméstico, serían más propensas a crímenes pasionales, pues se especulaba que éstas sólo mataban por amor. Además de crímenes amorosos, las mujeres podían verse envueltas en una situación desesperadora que las induciría al infanticidio, ya que siendo este crimen de tipo pasional por ser originado en el rescate del honor perdido y cometido durante un estado "afectivo patológico", que se veía motivado por el estigma y la vergüenza social que podría enfrentar la madre con un hijo ilegítimo, podía llevarla perfectamente al asesinato de su criatura acabada de nacer. En este sentido, las infanticidas fueron mujeres que se consideraron alienadas por sufrir de lo que se conocería como locura puerperal, un estado físico-psicológico dado después del parto y en el cual la madre podía experimentar ciertos cambios de comportamiento guiados por un sentimiento de descontrol y depresión. La locura puerperal fue un tema ampliamente discutido, sobre todo para finales del siglo XIX y principios del XX. Este estado, considerado tan delicado para la mujer, recibió amplia atención por parte de los médicos-legalistas en función de los disturbios que se presentaban en la mujer embarazada, parturiente o post-parturiente que podían conducirla muchas veces al crimen, especialmente al infanticidio.

El punto neurálgico de los debates sobre infanticidio se relacionaba con respecto a su penalización, especialmente dentro del Código Penal brasilero de 1890 y su principal atenuante, el honor. Así, algunos entendían que como los infanticidios eran delitos que no llegaban a ser juzgados en la justicia, la probabilidad de su existencia era nula y se vanagloriaban de ser un país en donde tal situación era así, diferentemente de otros países europeos donde las penas eran muchísimo más severas en función de su alto índice. Por otra parte, otros médicos-legalistas ${ }^{2}$, hicieron duras críticas a los artículos referentes al infanticidio sobre todo dentro del Código Penal de 1890, donde se estableció un tiempo determinado de siete días para el término recién nacido (con lo cual muchos no estaban de acuerdo y se adherían al pensamiento del Dr. Souza Lima quien expresaba que un recién nacido era aquel que no excedía de 24 horas de nacido) y en cuanto a las penas que eran relativamente más blandas en comparación con otros países europeos como Francia y Portugal donde se castigaba con la pena de muerte.

Para ciertos especialistas, como Augusto Militão Pacheco (1893, p. 9-19), la mujer infanticida merecía no sólo una condena dura, sino inclusive la pena de muerte. El honor, muy alegado en los juicios de infanticidio, sirvió en muchos casos para ablandar la pena de la acusada, sin embargo, de acuerdo con la mayoría de las tesis revisadas, estos autores eran contrarios a esta idea: “onde há honra não será preciso a intervenção caritativa do legislador, assim como, onde ela não existir, por mais expresso que seja o véu com que se encubra a devassidão, o escândalo sempre aparecerá" (ibídem, p. 19). Para estos profesionales, alegar vergüenza no justificaba la 
actuación de una madre asesina; la juzgaban incapaz de defender un honor que ya tenía por perdido al cometer el pecado amoroso y por tanto era imposible refugiarse en una cosa inexistente.

La madre infanticida que usaba como atenuante el querer salvaguardar su honor, de acuerdo con João Gonçalves Lopes Filho (1894, p. 9), era doblemente criminal: "Tal vez haja nisto uma razão de ser, porem entendo que seria uma agravante, pois ai seriam dois crimes: um da honra e outro do infanticídio, e ainda mais, a mãe matando a criança encobre a desonra?". Surge de igual forma la contradicción existente entre las infanticidas y el amor maternal, ya que actuando como asesina iba en contra de su propia naturaleza y su designio de madre. Otro punto importante que estaba relacionado directamente con el honor, tiene que ver con la legitimidad del recién nacido y su identidad como peso ante la ley, pues un embarazo ilegítimo no daba a la madre la categoría de honrada. En este sentido, las infanticidas eran mujeres que actuaban guiadas por un sentimiento de perversidad.

Comienzan de esta forma las defensas en función del infanticidio Honoris Causa. Estos manifiestos fueron realmente extraños, porque de veinte tesis revisadas sobre infanticidio, sólo dos doctorandos se expresaron a favor de esta idea. Se pone de manifiesto la importancia de tomar en cuenta la locura puerperal. Conjuntamente, se argumenta la supuesta poca peligrosidad que representaba una infanticida para la sociedad; en primer lugar, porque el infanticidio era un tipo de crimen pasional, de alienación mental, con un motivo único, que sería poco probable de repetición y segundo porque el daño que causaba a la sociedad era mínimo al privarla de una vida aún sin identidad. Por esa razón, la infanticida merecía una pena más blanda.

En definitiva, se observa cómo el tema del infanticidio y principalmente sus causas fueron ampliamente abordadas en estas tesis. Especialmente, cobra más vigor a partir de la segunda mitad del siglo XIX para traspasar esa discusión hacia la racionalización de la locura puerperal como causa de tales delitos, sobre todo durante la primera mitad del siglo XX. Al mismo tiempo, se percibe que no fue ni consonante, ni fácil tratar este tema porque había muchos elementos en juego, sobre todo los de orden moral. En este sentido, queda expreso que la defensa de la honra de una mujer que asesinaba a su propio hijo acabado de nacer era delicada porque llegaba al extremo de ser tan ambivalente como los mismos juicios y sentencias de estos crímenes. Defensas y detractores envuelven las disputas de estos especialistas en medicina, donde básicamente comenzaban las controversias, que sin duda alguna se hacían mucho más complejas al momento de juzgar a una madre infanticida.

\section{Las protagonistas}

Como ha resultado en otros trabajos realizados sobre este tema, para regiones como Argentina $^{3}$, Colombia $^{4}$, México $^{5}$, Venezuela ${ }^{6}$, Francia $^{7}$, Italia $^{8}$, Portugal $^{9}$ y el mismo Brasil $^{10}$, de 31 casos aquí examinados comprendidos entre 1841 y 1936, se encontraron 31 acusados, siendo que, de éstos, sólo aparecen (5) hombres como denunciados, aquellos que tuvieron la singularidad de ser los mismos padres de las pequeñas víctimas. Especialmente, las 26 mujeres denunciadas, de las cuales se trabajará ampliamente 
en este apartado, representaron el $83,9 \%$ del total de los 31 casos donde se conoce la identidad del o la acusada. Estas mujeres fueron, en su mayoría brasileñas 80,8\%, seguidas por inmigrantes portuguesas 15,4\%, especialmente jóvenes, cuya edad comprendía entre los $15-20$ años $42,3 \%$ y entre los $21-25$ años 23,1\%.

Estas intimadas eran en su mayoría solteras $76,9 \%$, seguidas de casadas $19,2 \%$ y particularmente pretas (negras) $26,9 \%$, seguidas de blancas $23 \%$ y pardas $11,5 \%$. Realizaban diversas actividades, todas relacionadas con los llamados "trabajos mujeriles" como lavar, coser, cocinar, limpiar, oficios que serán encuadrados dentro del término "Domésticas" y figuran en $47,6 \%$, de las 21 procesadas en donde se establece este dato, siendo ellas "amas de casa”, dedicándose a los quehaceres del hogar, sobre todo cuando vivían con sus padres o algún familiar. También cabe la posibilidad de que estas jóvenes realizarán algún tipo de actividad remunerada dentro de sus hogares, siendo sin duda una extensión de sus actividades cotidianas dentro de la casa. Sin embargo, la mayoría de las encausadas analizadas eran trabajadoras en el servicio doméstico 52,4\%, es decir, que se ocupaban como empleadas en casas de familias para cocinar, limpiar, lavar o cuidar niños (amas secas). En este tipo de labor, también podían permanecer como agregadas, lo que significaba que no recibían salario, sólo vivían de favor por comida, techo y vestido. Otras, recibían un pago que era bastante precario y contaban con un día de descanso, siendo que todas compartían la necesidad de vigilancia y control masculino.

La mayor parte de las denunciadas por infanticidio estudiadas no poseían algún tipo de instrucción, siendo, por tanto, 61,5\% analfabetas, otras, 34,6\%, escasamente sabían leer y escribir o por lo menos escribir su nombre, situación que es compatible con los datos mostrados en el primer censo nacional del año 1872, donde se afirma que solamente el $11,5 \%$ de la población femenina sabía leer y escribir, mientras que sus pares masculinos representaron cerca del 19,8\% (BRETAS, 1997, p.18). Estas denunciadas provenían de diversas partes del Estado de Río de Janeiro, siendo algunas de la Capital, Campos, Campo Grande, Jacarepaguá, Cabo Frio, Niterói, São Gonçalo. Algunas venían de otros estados aledaños como Minas Gerais y de otros más alejados como Bahía o Sergipe. Esta característica explica muy bien que estas acusadas eran mujeres que procedían del interior del Estado de Río o de otros lugares en búsqueda de mejores condiciones de trabajo. En el caso de las 4 portuguesas que fueron acusadas de infanticidio, también provenían de provincias rurales y pobres de aquel país, como Beira Alta, Paradela y Pombal, circunstancia que las dejaba solas, en situación inestable y sin redes sociales de ayuda.

A través de la observación de los datos examinados en este trabajo, se puede establecer que aquellas indiciadas fueron en su mayoría mujeres jóvenes pobres, solteras, analfabetas y que se dedicaban a trabajar como servicio doméstico, realidad bastante consonante con el contexto social que vivía Río de Janeiro durante esta época, siendo que la realidad de la ciudad estuvo marcada por el desequilibrio entre la oferta de trabajo y la demanda de mano de obra, situación que se agudizó con la crisis de la esclavitud, ya que la mano de obra disponible en la ciudad tendió a aumentar por la presencia de ex esclavos, por la llegada de libertos provenientes de zonas rurales y por la presencia cada vez más determinante de inmigrantes. 
Estas mujeres fueron clasificadas como negras y blancas. La presencia de pretas (negras), por ejemplo, puede ser explicada a través de la fuerte representación de población ex-esclava que quedó deambulando después de la abolición de la esclavitud en 1888, permaneciendo mayoritariamente sin ocupación, lo que representó a partir de ese momento un tipo de población a la que se dirigía el interés por ocupar y normalizar a través del trabajo, de modo que fueran "higienizadas".

En lo que se refiere a las blancas, hay que considerar que éstas aparecen posiblemente justificadas por la cantidad de portuguesas inmigrantes de regiones pobres que llegaron a Brasil a finales del siglo XIX y principios del $X X$ en búsqueda de mejores condiciones de vida. Es de recordar que la mayor parte del crecimiento poblacional de Río de Janeiro se dio entre los años 1890 a 1906 como consecuencia inmediata de la presencia de inmigrantes europeos provenientes no sólo de Portugal, sino también de regiones de España e Italia. Para 1906, la ciudad de Río de Janeiro contaba con más de 500 mil habitantes, seguidas solamente por las ciudades de Salvador y São Paulo con 200 mil cada una.

Este rápido crecimiento poblacional también estuvo relacionado con la migración de esclavos libertos de las zonas rurales a la urbana, a la intensificación de la inmigración, como se expuso y a las mejores condiciones de saneamiento. Para finales del siglo XIX, especialmente los portugueses representaban 20\% del total de la población de Río, siendo que, para el censo de 1906, aunque no se tienen datos tan específicos, se sabe que la crisis de desempleo y el estancamiento económico en Portugal, contribuyeron a aumentar ese flujo migratorio en la ciudad. Sin embargo, como afirma Magali Engel (2004, p. 24), la precariedad de la sobrevivencia de estas mujeres pobres, migrantes o no, se hizo mucho más difícil al enfrentar la existencia de preconceptos ligados a los trabajos que ejercían como las lavanderas, quintadeiras, vendedoras de quitutes, artesanas, costureras o las que se arriesgaron a ejercer otro tipo de actividades como adivinas, coristas, bailarinas, cantantes, actrices y prostitutas, siendo todas estas ocupaciones profundamente despreciadas en la época.

Es de recordar igualmente que Río también sirvió como capital de atracción que aproximaba personas que llegaban no sólo con la intención de negocios, sino también de diversión. Algunos viajantes y escritores se referían a la misma como ciudad "pecaminosa" con la presencia de individuos de conducta relajada que bebían y se divertían, además de la innegable visibilidad de mujeres de toda clase en conductas relajadas y groseras, en fin, para algunos, "tierras de todos los demonios", "tierra de todas las tentaciones". Desde el principio, la colonización portuguesa trajo consigo a los nuevos territorios conquistados la idea de restricción y vigilancia al amor, al mismo tiempo que transmitió el pensamiento de sexo como sinónimo de pecado. Reglamentar lo cotidiano, tanto por autoridades civiles como eclesiásticas, tuvo su principal dispositivo a través de la orientación ética, educación espiritual, evangelización, sermones y una de sus principales instituciones: la inquisición. Junto con eso, la Iglesia Católica se apoderó de la idea patriarcal para normalizar las relaciones entre los sexos, entendidas como relaciones de poder y dominación, que particularmente 
en Brasil comenzaron con la esclavitud a partir del siglo XVI, y que consecuentemente fue reproducida de puertas para adentro en los hogares, asumiendo la idea de mujer sumisa, obediente y servil al marido.

Los trazos advertidos en los inquéritos y procesos sobre estas "infanticidas", revelan muchas veces situaciones infelices de mujeres que fueron abandonadas por sus padres aún con tierna edad o que fueron obligadas ante la necesidad de sobrevivencia a dejar el hogar en el campo para emplearse en la gran ciudad, atraídas por las significativas oportunidades de empleo. Historias como la de Emília Faustina, preta de 18 años, soltera y de servicio doméstico, oriunda de Barra do Piraí, expone ese triste escenario:

[...] que com idade de sete anos foi entregue por seu pai a Arlindo de tal, que trazendo-a para esta Capital, colocando-a em uma casa de família... em Catumbi... que ali moudo-se para o Morro de São Claudio no Estácio de Sá, que nesta casa permaneceu seis anos, até que por ser muito maltratada pela dona da casa... que estive em casa de Gamboa de seis para sete anos... que há nove meses mais ou menos foi por Gamboa desvirgada [...] (Museu do Tribunal da Justiça. 1 Cartório do Júri do Distrito Federal. 14035. RG: 13244. Cx. 1403. Emília Faustina. 1903. F. 11r.).

Trayectorias como esta, fueron comunes a las implicadas y desnudan una realidad de mujeres que desde niñas sirvieron como empleadas en casa de familia, que, sometidas a la autoridad de un patrón o patrona, eran maltratadas y abusadas. No es de casualidad, que la mayoría de estas incriminadas vivieran donde trabajaban, lo que las dejaba a merced del jugo de sus patrones, siendo también constantemente vigiladas. Este tipo de vigilancia, implicaba cuestiones como no salir solas de la casa, a excepción de un pedido y en compañía o dar "confianzas" hablando con hombres extraños en los portones de las residencias; todo ello no era más que una supervisión de su comportamiento sexual. No eran bien vistas las empleadas que iban a bailes, al botiquín o al carnaval y mucho menos las que circulaban por las calles solas, sin oficio ni beneficio, pues el ocio fue considerado sinónimo de criminalidad. Otras, vivían solas o con algunas compañeras en cuartos alquilados llamados de "comodos", espacios que eran considerados de baja moralidad; lugares de demasiada intimidad, perdición y liviandad y que como explica Martha de Abreu Esteves (1989, p.71), también constituían una grande amenaza, pues la población pobre se concentraba allí, sobre todo en el centro de la ciudad, residiendo en este tipo de casas o en los llamados "becos" y "vilas" y por eso eran blanco de interés y críticas de las reformas urbanas como lugares a ser especialmente higienizados.

Otra realidad presente en la vida de estas enjuiciadas es que algunas como Olivia Nogueira da Gama desconocía su procedencia, a sus padres y su propia edad, mujeres que ignoraban su propia identidad. En otros casos, algunas de estas denunciadas tuvieron una crianza en hogares considerados "desestructurados", casas en donde aquellas generalmente vivían con su madre jefe de familia, una madre soltera, casada o separada, muchas veces "amasiadas" con un compañero más joven. Estas madres 
trataban de ejercer cierta vigilancia sobre sus hijas jóvenes, tarea que les fue difícil de desempeñar, sobre todo cuando aquellas tenían necesidad de salir para trabajar, para ir al mercado o para recrearse. La calle no era un espacio desconocido para las mujeres pobres, ellas transitaban tanto por su necesidad de sobrevivencia como también por el deseo de diversión. No obstante, no es de olvidarse que este tipo de salidas fueron consideradas actitudes peligrosas, de hecho, la presencia femenina en lugares públicos sirvió de motivo para desconfianzas y habladurías, las "desclasificadas", como eran consideradas aquellas que transitaban las calles y avenidas, sobre todo vendedoras ambulantes y lavanderas se convirtieron en el foco, no sólo de los higienistas, sino también de los vecinos que "falavam".

Esta fue la realidad vivida por las acusadas de asesinar a sus recién nacidos durante el periodo en estudio, escenario que será un poco más ampliado adelante. ¿Y qué acontecía con los acusados, con los hombres que mataron también a sus recién nacidos? Se sabe que el infanticidio es un tipo de crimen de exclusividad femenina, y por esta razón, la mayoría de los trabajos que tratan el tema, abordan a las madres como principal foco de análisis, pues lógicamente es en ella que convergen los elementos esenciales de este tipo de delito. Sin embargo, en esta investigación se cuentan con los valiosos datos de cinco hombres incriminados que tienen la característica de ser los mismos padres de las criaturas asesinadas, situación que es igualmente razonable al recordar que el infanticidio es un crimen bien especial y que su motivación es, asimismo, bien diferenciada.

La edad de estos personajes comprendía entre 20-30 años y mayores de 31 años. Sólo en dos de ellos se estableció su grupo étnico, siendo clasificados como blancos, igualmente, tres eran solteros y dos casados, con profesiones diversas: barquero, granjero, militar y un zapatero, tres de ellos sabían leer y escribir o escribir su nombre e infelizmente de los otros dos no se menciona su grado de instrucción. Tres eran brasileños y dos portugueses, lo que podría explicar esa condición de ser considerados blancos. Se puede apreciar también, que los primeros dos casos hallados donde estos hombres fueron acusados de infanticidio sucedieron en áreas rurales, respectivamente en São Gonçalo y Niterói. Cuatro de ellos fueron imputados por asesinar a sus hijos después de nacer y el otro, además de infanticidio, también fue denunciado por estuprar a su propia hija.

Caso destacado fue el de Tertuliano Cardozo Leal, de 22 años, soltero y barquero quien en 1889 fue acusado de asesinar a su hijo recién nacido fruto de las relaciones incestuosas que mantenía con su hermana Rosa Cândida Leal. Fue condenado en 1890 a 12 años de prisión, grado máximo del Art. 197 del Código Criminal de 1830 que rezaba: "Matar algum recém-nascido. Penas: de prisão por três a doce anos, e de multa correspondente a metade do tempo". De esta forma, se aprecia que Tertuliano fue encajado dentro de las penas equiparadas para el homicidio de un recién nacido, pues el Código Criminal no contempla dentro del infanticidio la figura del padre como ejecutor del crimen. 


\section{Las acusadas y sus "hablas"}

Las "voces" de las acusadas pueden ser rescatadas en trazos, trazos que se desvendan en las entrelíneas de los procesos e inquéritos a los que fueron sometidas y vehiculadas a través de un discurso dirigido, netamente masculino, de delegados, comisarios, médicos, abogados y en ciertos casos de maridos, hermanos y padres. Esos pequeños pliegues que sobrenadaron en un mundo de palabras bastante técnicas, quedaron plasmados en el papel y sirven como un valioso recurso al qué apelar para intentar descubrirlos. Esos instrumentos son básicamente las declaraciones, interrogatorios y confesiones a las que fueron supeditadas esas mujeres que acababan de ser descubiertas y denunciadas por un crimen atroz, que sentían miedo, tristeza, rabia, pero sobre todo que quedaban en estado deplorable de salud después haber dado a luz recientemente y en circunstancias extraordinarias, hecho que les fue difícil de esconder o disimular.

Los primeros interrogatorios eran determinantes para establecer responsabilidades en las intimadas. Muchas, al ser sorprendidas con evidencias contundentes de sus actos, conseguían negar vehementemente los hechos, otras, ya debilitadas, enfermas y sobre todo agobiadas de silencios, confesaban inmediatamente su crimen. Sus historias se dividieron entre el amor ilícito o la pasión desmedida que sentían por algún hombre y la obediencia y recato que no supieron mantener. Quedando embarazadas, siendo luego, abandonadas o despreciadas, encontrándose solas, decidían ocultar su gravidez y finalmente, cuando el parto las acometía, llegaban a un desenlace desesperado que las empujaba a eliminar la prueba que las condenaba. Los amores, el deseo y la pasión comenzaban cuando se hacían amantes o concubinas de un hombre, tal vez comprometido, situación que, en su calidad de solteras, por ejemplo, representaba una transgresión al modelo de mujer virgen que debía ser. Este tipo de relaciones de amancebamientos y de encuentros fugaces con novios, prometidos o amantes en que se les prometía matrimonio, se evidencian a través de la lectura de los documentos y demuestran a la vez, que los infanticidios analizados fueron la consecuencia de esas relaciones consideradas socialmente como ilícitas.

Una de las características comunes en las historias de estas acusadas es que siempre escondían su embarazo, algunas viviendo en casas de sus patrones como empleadas y otras en casa de sus padres, hermanos o familiar de autoridad, se sentían presionadas ante esa situación que las atemorizaba. Este recelo era de carácter moral, sobre todo porque en su mayoría eran solteras y habían tenido contactos íntimos con sus compañeros en el más absoluto secreto. El tipo de relacionamiento establecido con sus prometidos, novios, amantes o concubinos, muchas veces no les dio la garantía de un futuro estable, como, por ejemplo, la realización de un matrimonio, por esa razón, temerosas de las consecuencias de sus "deslices" disimularon a todo precio el fruto de tales uniones. Era común, que, al ser descubiertas, en sus declaraciones iniciales negasen ser las autoras del crimen, defendiéndose de las sospechas como "honestas" y por lo tanto "virgens".

Pero, ¿por qué mataban estas mujeres?, ¿cómo justificaban sus actos?, ¿qué las llevaba a la decisión desesperada de atentar contra la vida de sus propios hijos?, ¿de 
qué o a quiénes temían? Cuando la situación se hacía insostenible y presionadas, descubiertas y muchas veces con semblante caótico o de cama en la Santa Casa de la Misericordia, decidían "hablar", "confesar", "explicar" su realidad y algunas lo hacían bajo una especificidad impresionante, con detalles del crimen que a veces asombraba, con indiferencia, tal vez, con recelo de las autoridades y en otros casos, con remordimientos. Expresiones como "la criatura nació muerta, "murió por una caída", "estaba sola y sin fuerzas", "tomó un purgante", "no sabía que estaba embarazada", "sufría de hinchazón", "recibió un grande susto", "se cayó de la escalera”, "nunca estuvo enferma”, "no sabía que era crimen”, "no sabía que había morgue”, "perdió los sentidos", "vergüenza" y "deshonra", fueron constantes en las confesiones de las acusadas.

Con esas manifestaciones, se puede revelar algunas de las motivaciones y justificaciones que hacían las intimadas. Dentro de las particularidades de cada caso, pueden ser encontradas coincidencias que llevan a establecer generalidades en los procesos estudiados. De tal manera, por ejemplo, Alice do Espirito Santo, de 18 años, soltera y de servicios domésticos daba em 1902 en su confesión detalles de lo ocorrido durante el crimen: "[...] sentindo dores de parto dirigiu-se para um quarto dos fundos da casa e ali tive uma criança do sexo masculino... que ocultou a criança em um baú de folha existente no referido quarto, e bem assim roupas molhadas sangue [...]" (Museu do Tribunal da Justiça. 1 Cartório do Júri do Distrito Federal. 14033. RG:13242. Cx. 1403. Alice do Espirito Santo. 1902. F. 7r-v.). Un año después, en 1903, Emília Faustina, preta de 18 años, doméstica y analfabeta, relataba igualmente lo acontecido durante su parto:

[...] que no dia dois do corrente sentindo dores de parto, foi ao quintal à noite, em uma touceira de bananeira, deu à luz a uma criança do sexo masculino que nascendo viva, a declarante com o fim de ocultar a sua desonra... a enterrou ainda viva... julgando ter no momento de comete-lo perdido a razão [...] (Museu do Tribunal da Justiça. $1{ }^{\circ}$ Cartório do Júri do Distrito Federal. 14035. RG: 13244. Cx. 1403. Emília Faustina. 1903. F. 11r.).

Olivia Nogueira da Gama, al ser acusada en 1904, excusaba su delito apelando a la pérdida de los sentidos, pero también a la vergüenza que sentía al convertirse en madre soltera. Etelvina de Aguiar, de 18 años, soltera y de servicios domésticos, en 1906, aclaraba la muerte de su hijo al indicar que "espantou-se com um papel que estaba na parede da cozinha" y por eso recibió un "gran susto", lo que le provocara un "aborto", naciendo su hijo muerto. Un año después, Delmira Maria da Conceição, preta también de 18 años, soltera y doméstica, usó el mismo argumento para defenderse de la acusación en su contra, adicionado que 'em casa de sua patroa todos notavam que seu ventre estaba um tanto crescido, porém, ela declarante sempre negara que estivesse gravida por ter vergonha" (BR.AN.RIO.T8.O.PCR.2480. F. 8v.). Angélica de Lourdes, indígena de 16 años, soltera, doméstica y analfabeta, al ser acusada en 1911 de dar a luz a un niño y aparecer este muerto con señales de violencia, se justificaba 
con la pérdida de los sentidos como consecuencia del parto que había sufrido sin asistencia, pero también alegaba cierta ignorancia de lo que le acontecía.

En 1932, Maria Augusta, preta de 18 años, soltera y doméstica, disculpaba la muerte de su niño diciendo que éste había nacido muerto, escondiendo después el hecho por miedo de que su patrona descubriese que había parido una criatura. Luiza da Silva Senna, además de justificar lo que sucedió con su hijo recién nacido atribuyéndolo a que aquel había nacido muerto, también intentó alegar vergüenza al abandonar a la criatura en el monte, ya que "voltou para sua casa, ocultando o que tinha passado a sua mãe por ter... vergonha da falta que cometera... que ocultou o fato sempre... por medo como já disse e casar-se-ia com ele [Manoel Vieira] se o mesmo tivesse feito o que prometeu [...] (BR.AN.RIO.CS.O.IQP.488. F. 5v-6v.). Un argumento parecido usó Maria Antônia da Conceição, quien en 1910, manifestaba sentirse avergonzada al quedar embarazada al mantener relaciones sexuales secretas y quedar embarazada de su primo "que vendo ela declarante que a criança havia nascido sem vida, procurou ocultar a sua família tal fato e por isso levou o feto... para o quintal enterrando-o" (BR. AN.RIO.MW.O.IQP.2634. F. 9v.).

Para ese mismo año, la portuguesa Joaquina Gonçalves, blanca de 35 años, casada y de servicios domésticos, fue imputada de asesinar a su hijo después del parto envolviéndolo en paños mojados y llenos de sangre para después esconderlo debajo de la cama donde dormía con su marido. Las sospechas recayeron sobre ella al ser descubierto el cadáver, pero mucho más porque aquella supuestamente había escondido su gravidez, incluso al marido, del cual se había reunido desde Portugal pocos meses antes. En su interrogatorio, exponía que tenía recelo de las desconfianzas de su esposo, desconfianzas bien fundadas como se verá más adelante y también vergüenza de las otras personas que residían con ellos en una casa donde alquilaron un "cômodo": [...] ela Ihe negava por lhe parecer que o seu marido tivesse suspeitas que o filho não fosse seu... que tive vergonha das pessoas da casa razão porque ali colocou a declarante o cadáver de seu filho supondo que ele tivesse nascido morto [...] (Museu do Tribunal da Justiça. $4^{\circ}$ Cartório do Júri do Distrito Federal. 5173. RG: 4382. Cx. 577. Joaquina Gonçalves. 1910. Fls. 21v-22r).

De esta manera, las "infanticidas", denunciadas, acusadas, descubiertas e interpeladas, usaron básicamente dos formas de defenderse; primero, las que siempre alegaron una especie de "inocencia" del asesinato de las criaturas porque expresaban que las criaturas habían nacido muertas por alguna circunstancia ocurrida anteriormente como caídas o sustos, que la muerte se dio como consecuencia del parto o que el deceso había sucedido sin su culpa, pues ocurrió en momentos en que estaban adormecidas, débiles, sin fuerzas y fuera de sus "sentidos", por tanto al descubrir que los infantes estaban ya sin vida, tomaban la decisión, por ignorancia, de enterrarlos o desaparecerlos porque ignoraban que era un crimen deshacerse de los hijos de esa forma o porque era de costumbre enterrar los mortinatos en los patios o terrenos cercanos a la casa. La otra forma de protegerse, surgían cuando las pruebas eran evidentes en su contra o decidían agobiadas confesar, en este sentido, las que reconocieron haber matado a sus hijos, justificaban lo que hicieron porque 
habían "perdido los sentidos", o por miedo y recelo de que sus patrones descubrieran su condición y ser despedidas, o por vergüenza de que sus familiares entendieran que se habían convertido en madres solteras. Muchas no dudaron en apelar a varias de estas circunstancias para excusarse.

\section{La prueba que delataba}

Sí al hablar de protagonistas resulta difícil reconstruir esos trazos, esos trechos de vida dejados en el papel, recuperar los pocos instantes de existencia de las criaturas, víctimas de infanticidio, implica una tarea aún mayor. Precisamente, la peculiaridad de estos casos, en donde en las víctimas debían concurrir ciertos criterios bien específicos, como el de comprobarse su vida después del parto, hace de ellos infantes a los cuales sólo se tiene acceso a través de las informaciones, tanto de los testigos como de las acusadas, así como también por medio de las pericias realizadas en sus pequeños cuerpos. La existencia de ellos se revelaba al mundo de forma brusca, triste y escandalosa, pues cuando se hallaba un recién nacido muerto, con señales de violencia y muchas veces en estado de putrefacción, las alarmas se encendían, las personas murmuraban y corrían la voz del descubrimiento. Este tipo de encuentros, siempre simbolizó asombro, indignación, condena, pero igualmente, curiosidad.

El infortunio de toparse con un hallazgo de esta naturaleza tomó por sorpresa en los casos analizados a diversos individuos, desde niños, parientes, vecinos y las propias autoridades. La noticia se expandía rápidamente, al punto de convertirse en pocas horas en un suceso denunciado, incluso en los diversos periódicos de la época. Es innegable que el aparecimiento de cadáveres de recién nacidos fue un hecho común, no sólo en Río de Janeiro, sino en diversos lugares, situación con la que muchas sociedades aprendieron a lidiar. En Río, la desgracia se hizo evidente en 32 víctimas de mayoría masculina 62,5\%, en comparación con las niñas 34,4\%, criaturas que fueron asesinadas, víctimas del maltrato, abandono y violencia por parte de sus progenitores. Párvulos, que en los 20 casos donde se indica su color, fueron mayoritariamente considerados blancos $70 \%$, seguidos de pardos $15 \%$ y pretos $15 \%$, recién nacidos $81,3 \%$, es decir, que su muerte ocurrió inmediatamente después del parto y en menos de 24 horas después de él; niños que no tenían nombre 90,6\% o bautismo $84,4 \%$ y que tampoco fueron inscritos en el registro civil.

Estas últimas singularidades, se comprenden porque fueron criaturas que tuvieron pocos minutos de aliento y que generalmente nacieron en condiciones precarias, insalubres y en secreto. Sus madres tuvieron partos que fueron la última consecuencia de mantener su embarazo en oculto, ya que decidieron enfrentar dar a luz a solas, sin ayuda y en lugares apartados. Mucho más remotos fueron los sitios en que algunas de esas víctimas fueron encontradas, sufriendo las inclemencias del clima y el ataque de animales. Estos pequeños no recibieron "las aguas" y mucho menos un bautizo católico, condición que a los ojos de la sociedad implicaba reconocer y presentar a la comunidad cristiana la existencia de un alma más. Precisamente, uno de los objetivos de esta ceremonia era evitar el peligro de que los recién nacidos perecieran sin estar bautizados, lo que mandaría al inocente directo al limbo. Es de recordar, asimismo, que 
el bautismo se consagró no solamente como un ritual de purificación y de promesa a la Iglesia Católica, sino equivalentemente también fue como una forma fastuosa de dar entrada a estas criaturas dentro de las estructuras familiares y sociales.

\section{La otra cara de la moneda}

Al estudiarse casos de infanticidio a través de procesos-inquéritos criminales, los protagonistas de este escenario suelen ser las acusadas; madres que por algún recelo decidieron suprimir el fruto de su vientre, causando escándalo y repulsión precisamente cuando el crimen se hacía público, las víctimas, y los padres de las mismas. Esa publicidad, colocaba a las investigadas en el centro de atención en las indagaciones que se hacían del hecho donde abogados, médicos y jueces exponían su vida, su pasado, su comportamiento, sus sentimientos, pero ¿qué ocurría con la otra parte, que generalmente quedaba incompleta o ausente en la mayoría de este tipo de procesos? La otra cara de la moneda, simbolizaba la paternidad, el padre de la criatura asesinada que, siendo actor principal, coprotagonista de la coyuntura, quedaba muchas veces bajo la cortina de humo del anonimato. Esta característica, se daba porque las indiciadas no hablaban de ellos, no los comprometían directa o indirectamente en su “desgraça”, ellas, tal vez por vergüenza, miedo, aprensión a la exhibición pública de sus compañeros o a hacer mucho más complicada su situación, callaban, omitían, protegían.

De los trabajos que han analizado infanticidios, sólo pocos hacen alguna vaga referencia a esa otra mitad, lo que indudablemente deja un vacío en el rompecabezas que implica para el investigador reconstruir la historia de esas "infanticidas". Particularmente, este estudio tiene la fortuna de contar con esos datos, en $74,2 \%$ del total de 31 casos analizados se conoce la paternidad de esos infantes. Esta cifra es de suprema importancia, no sólo porque 5 de ellos fueron directamente acusados de asesinar a sus hijos recién nacidos, sino, porque, precisamente, permite llenar ese espacio, esa carencia de entender la otra cara de la moneda. A medida que se explora este contexto, se puede encajar de forma más clara la singularidad de esas historias, que se exponen bastante fragmentadas a través de la documentación.

Los padres de las víctimas de infanticidio en Río de Janeiro fueron en su mayoría hombres que superaban la edad de sus compañeras, de los 16 casos en los que se establece este dato, se muestra que su edad comprendía una faja etaria entre los 21-25 años con 31,3\%, y de $26-30$ años con $18,8 \%$, siendo este mismo porcentaje de 31-35 años y mayores de 36 años. Destacadamente, por ejemplo, había hombres muy jóvenes, casi de la misma edad de sus parejas con 19 años y otros mucho mayores, de 55 y 57 años. En su mayoría brasileños 52,4\% y portugueses 42,9\%, blancos $84,6 \%$, solteros $55,6 \%$, y casados $38,9 \%$. Contrariamente a sus compañeras, sabían leer y escribir o al menos escribir su nombre 64,7\%, con un índice de analfabetas de 35,3\%. Al mismo tiempo, se ocupaban en diversas actividades, como negocios (2), operários (obreros) (2), labrador (2), militar (2) y por demás uno de cada ítem: albañil, barquero, carnicero, jardinero y lechero, condición que demuestra que estos individuos realizaban actividades mucho más variadas que sus parejas y que para algunos refleja 
una situación económica estable, pero para otros, sus empleos eran típicos de ser ocupados por hombres pobres.

De estos resultados se puede inferir que los vínculos creados entre estos protagonistas incluyeron diversidad de escenarios que, a pesar de intentos de realizar un patrón general común a todos, resulta difícil no atender a sus individualidades. Estadísticamente hablando, de los 31 casos analizados de infanticidio en sólo 23 de ellos se pudo establecer esta conexión, siendo que la mayoría de estas relaciones se establecieron entre mujeres y hombres que fueron mayoritariamente amantes $30,4 \%$, parejas solteras que se encontraban esporádicamente para mantener amores o donde uno era casado y el otro soltero. El tipo de uniones constituidas entre una acusada que era soltera y el padre de su hijo siendo casado $13 \%$, se aprecia sobre todo entre las empleadas de servicio doméstico y su patrón. Los casos específicos hallados mostrando este tipo de vínculos, revelan que la posición frágil de la mujer como empleada doméstica les hacía quedar bajo la "protección" de esa autoridad masculina, que no sólo se establecía por ser su patrono y depender económicamente de sus empleos, sino también porque esas empleadas eran condicionadas a la obediencia y sumisión, sobre todo de carácter moral, a ese dominio patriarcal. Los modelos impuestos supeditaban no sólo su vivencia, sino asimismo su pensamiento y sentimientos de no poder infringir las normas. Mujeres solteras, jóvenes y dependientes económica y moralmente de sus señores, muchas veces sucumbían, concordando o no a los deseos sexuales de aquellos.

Otra categoría que se evalúa en los casos analizados, es la de estar la madre y el padre de las criaturas asesinadas casados. Aquellas relaciones donde los protagonistas eran namorados (novios), representó un 13\% de los casos trabajados. Los concubinos que se observan en los casos estudiados, representan $8,7 \%$ del total de las relaciones establecidas entre las acusadas de infanticidio y sus compañeros, un porcentaje bastante bajo que sólo se evidenció en dos casos. Este tipo de uniones se caracterizaron por ser indiferentemente de su estado civil los protagonistas, convivir juntos. Por otro lado, el único caso hallado donde los protagonistas estaban comprometidos, o noivando, es el de los pretos Delmira Maria da Conceição, de 18 años, de servicio doméstico y Juvencio Benedito Barboza, de 21 años y operário (obrero), quienes en 1907 ya mantenían un año de amores y se pretendían casar cuando Delmira quedó embarazada, razón por la cual ocultó su estado a sus patrones. Las relaciones incestuosas estuvieron representadas por tres casos del conjunto analizado.

\section{El proceso}

El hallazgo de un pequeño cadáver, de un recién nacido muerto en la vía pública, enterrado, abandonado con señales de haber sufrido maltrato, generaba indignación y murmullos en la colectividad. Es cierto que cuando se descubría un hecho de tal naturaleza, las personas, vecinos, patrones, empleadas y familiares, tenían reacciones de asombro, sospecha, pesar, tristeza, curiosidad, pero también sentían un poco de morbo. En los casos de infanticidio, se hizo común que los vecinos tuvieran altas probabilidades de toparse con estos infelices descubrimientos, siendo que, en muchas ocasiones, las criaturas después de muertas o asesinadas eran abandonadas, 
sepultadas o lanzadas al mar con la finalidad de desaparecer sus pequeños cuerpos. En otros casos, las madres eran descubiertas antes de que eso aconteciera, lo que de igual forma también significó una desagradable sorpresa para patrones y familiares que localizaban algunos fetos acabados de nacer en condiciones deplorables.

Este tipo de situaciones, no fueron ajenas a los casos analizados en Río de Janeiro, en donde los mismos descubridores sirvieron como denunciantes ante la policía y revelaban el lamentable suceso. Los espacios públicos, sirvieron de escenario para el aparecimiento de infantes asesinados y abandonados a manos de sus madres, que en el desespero de su condición (parto y posterior carga emocional) ante el temor de ser descubiertas de su "doble" criminalidad, se deshacían de sus hijos, incluso aún con vida, de la forma más rápida que encontraban. Fueron los vecinos $34,4 \%$, especialmente, quienes tuvieron el infortunio de cruzarse con tal realidad, entendiendo por vecinos como todas aquellas personas que residían o trabajaban cerca del lugar donde se cometía el crimen o donde se abandonaba el cuerpo del recién nacido. Se incluye en esta categoría también aquellos individuos que transitaban por estos locales y percibían el hallazgo.

En otros casos, era precisamente algún "praça” de policía o guardia nocturno quien colocaba la denuncia. Esta modalidad representó el 22,6\% del total de las quejas instauradas en los casos de infanticidio estudiados, entendiéndose que esto era una situación lógica cuando se piensa que podía ser la misma autoridad quien verificaba o descubría el crimen. En seis de los 31 casos analizados, funcionó como denunciante el patrón de las empleadas de servicio que fueron descubiertas después de haber asesinado, escondido o enterrado a sus hijos recién nacidos en sus propias residencias. Siguiendo esta lógica, en los casos en donde las “infanticidas” vivían con sus parientes, también fueron expuestas y acusadas por una autoridad masculina, ya sea hermano, padre o cuñado. Por otro lado, sólo en dos de los 31 casos analizados se presentó la modalidad en que era una partera quien iba hasta la policía con intención de denunciar un infanticidio. Lo excepcional de este tipo de acusadoras es que eran parteras extranjeras diplomadas y eran reconocidas como tal por médicos y autoridades.

\section{La columna vertebral del proceso}

La columna vertebral de los inquéritos o procesos estaba representada por las declaraciones de los testigos. Particularmente, en los casos de infanticidio los pocos testimonios a los cuales podía la autoridad apelar se restringían a familiares, patrones, vecinos y los propios policías, delegados o inspectores que investigaban el suceso. Esta característica se daba porque los infanticidios fueron delitos difíciles de descubrir, pero una vez que esto ocurría, probarlo implicaba un trabajo mayor, pues a diferencia de otros tipos de crímenes, eran cometidos en absoluta clandestinidad y por lo tanto sin testigos. Ante esto, los investigadores intentaban buscar el mayor número de personas que hubiesen escuchado o visto algo, y habiendo ya una incriminada, trataban de obtener de aquellas sus "verdades" con el fin de escudriñar, más que en el propio asesinato, en el pasado de la misma. 
En este sentido, los testimonios constituyeron dentro de las averiguaciones como una especie de rompecabezas que intentaba dilucidar la culpabilidad o no de la denunciada. No es de extrañarse que en este tipo de casos la participación de los testigos de sexo masculino fue imprescindible, pero, igualmente es cierto, que las autoridades recurrieron oportunamente a la declaración de mujeres, como madres, hermanas, compañeras de trabajo o cuarto, parteras, patronas o vecinas que estaban en intrínseca relación con el contexto de la acusada y del crimen. Estas mujeres podían ver, percibir, escuchar, sugerir, acusar e incluso desmentir situaciones íntimas de la denunciada, ejerciendo con ello redes de solidaridad o no, lo que podría demostrar al mismo tiempo, conflictos cotidianos que iban más allá de la simple denuncia. De esta forma, algunas veces sus pares masculinos sintieron que entraban en terrenos totalmente desconocidos, a excepción de los médicos como se verá más adelante. A pesar de la importancia y cantidad de testimonios femeninos, es indudable que los juicios de carácter moral hechos por los hombres pesaban más al momento de establecer categorías.

Tomando en consideración que la mayoría de las acusadas eran mujeres jóvenes y empleadas en el servicio doméstico, la participación dentro de los sumarios de patrones que colocaban la denuncia y patronas que descubrían el hecho fue determinante. Estos personajes no sólo denunciaban, sino que intervenían de forma activa dentro de las investigaciones con sus testimonios, ya que como explica Sidney Chalhoub (2001, p. 115), el patrón era una especie de "juez doméstico" que controlaba y aconsejaba a sus trabajadores a cambio de respeto y obediencia, siendo asimismo cierto, que esta circunstancia tenía por finalidad establecer un control social que intentaba minimizar las fricciones de una relación dada entre individuos de desigual condición. Justamente, eran especialmente las empleadas domésticas las que estaban sujetas a una supervisión diaria, no sólo de sus quehaceres, sino también de su comportamiento moral y sexual.

\section{Los crímenes}

Los casos estudiados de infanticidio que abarcan 95 años comprendidos entre 1841 y 1936, demuestran, como ha ocurrido en otras investigaciones, que son delitos que raramente llegan al conocimiento de las autoridades. No es de sorprenderse que pocos de estos casos estén conservados sí tomamos en consideración, el desconocimiento, la indiferencia y la burocracia administrativa de archivos e instituciones que los resguardan, además de la acción del tiempo que no pasa en vano. Reflexionando que, durante la primera mitad del siglo XIX, fueron hallados contados procesos de infanticidio, se puede alegar que las razones de tal situación, además de la pérdida o desorganización de los procesos. Estos factores no sólo son aplicables para principios del siglo XIX, sino también para el resto del periodo en estudio. Ciertas circunstancias variaron para finales de este siglo y principios del siguiente, ya que médicos, juristas y policiales centraron su atención hacia este tipo de crímenes y sus causas, basándose en un discurso de carácter profiláctico que intentaba curar esta clase de "males sociales". De esta manera, se expone que los años donde hubo mayor incidencia de infanticidios estuvo básicamente concentrada entre los años 1902 y 1912, teniendo su pico entre 1907 y 1908. ¿Esto significa que hubo un aumento de casos en este periodo? 
sí, o por lo menos más casos llegaron a conocimiento de la policía. Analizando este contexto, diversas variables pueden dar explicación a este fenómeno; el aumento de la población con impulso de la inmigración, sobre todo europea, las medidas de higiene aplicadas a la población y las reformas y saneamiento que recibió la ciudad especialmente entre 1904 y 1906.

A pesar de estas afirmaciones, hay que tomar cautela y no hacer generalizaciones en cuanto a la ocurrencia de los casos para estos años, ya que los datos analizados sin duda son una pequeña muestra de lo que fue ese universo de delitos. Con todo, es válido acrecentar que esa pequeña representación de índices no pasa desapercibida, es decir, que atendiendo a la dificultad que implica para el investigador trabajar con infanticidios, los datos analizados constituyen, sin duda, gran valor. En este sentido, ellos dejan ver que, para la ciudad de Río durante los años 1907 y 1908, las autoridades trabajaron con mayor número de casos que en años anteriores, e inclusive posteriores. Los procesos también dejan claro que la incidencia de los infanticidios fue escasa, pero constante, lo que daría una media de $(0,3)$ casos por año, siendo esto un crimen con incidencia realmente mínima, sí se compara con otro tipo de delitos como homicidios e incluso abortos y abandonos. Analizando más detenidamente estos datos, la ocurrencia de los mismos, de acuerdo a su categoría, ya sean inquéritos o procesos, refleja, por ejemplo, una incidencia exigua de inquéritos abiertos por infanticidio durante el periodo investigado, siendo una media de $(0,2)$ por año, estimándose el mismo valor para los procesos. En este sentido, los inquéritos podían ser más abundantes que los procesos, ya que las investigaciones que se hacían una vez que se conocía un crimen de este tipo muchas veces quedaron sujetas a falta de pruebas y por tanto eran archivadas. Llegar a un proceso de infanticidio fue una situación realmente excepcional.

De los 31 casos localizados sobre infanticidio, (15) de ellos acontecieron en la zona central de la ciudad, lo que representaría un 48,4\% del total de los casos analizados. En la región oeste, fueron encontrados (5) casos de infanticidio que incluyen Jacarepaguá, Realengo, Bangu y Campo Grande. Otros (5) crímenes fueron cometidos en el área norte de la ciudad; Engenho de Dentro, Tijuca y Cascadura, siendo que sólo se halló un sólo caso en la zona sur, en Laranjeiras. Las áreas rurales también aparecen representadas en los casos analizados, específicamente en Cabo Frío, Niterói, Nova Iguaçu y Magé, teniendo la particularidad de que dos de estos casos trataban de incesto e infanticidio.

Estos crímenes fueron cometidos en su mayoría de manera directa 75\%, pues los mismos ocurrieron especialmente por asfixia (estrangulamiento) con 33,3\%, seguidos por golpes en la cabeza $19 \%$, sepultamientos $14,3 \%$ y asfixia seguida de abandono $9,5 \%$. Los recién nacidos perecieron de forma inmediata y violenta, generalmente porque la madre actuaba contra la criatura inmediatamente después del parto, estrangulándolos con sus propias manos o trapos, golpeándolos en la cabeza contra el suelo, generándoles fracturas o aplastándolos con sus pies; otras los enterraban aún con vida o lo hacían ya como un medio para deshacerse del cuerpo o abandonaban el cadáver en lugares lejanos, donde suponían que la posibilidad de ser encontrados era mínima. 
Igualmente, hubo infanticidios perpetrados de manera indirecta, siendo que 25\% de éstos acontecieron por omisión; cuando la madre desamparaba al infante con la intención clara de que muriera, pues estos casos finalizaban siempre con el fallecimiento de la víctima. La modalidad de este tipo de infanticidios, podía darse cuando el recién nacido era dejado por la madre sin ligar su cordón umbilical y moría como consecuencia de una hemorragia, incluso muchas criaturas fueron abandonadas con todo y placenta en zonas apartadas donde pudieron ser atacados o devorados por animales y por tanto su sobrevivencia fue exigua. En este tipo de situaciones, era preciso determinar que el propósito de la madre en causar la muerte de su hijo era absoluto, con dolo, cuando no prestaba los auxilios suficientes para su sobrevivencia, de lo contrario, el caso podía juzgarse como un simple abandono.

En este sentido, probablemente muchos casos tratados como abandono pudieron ser casos de infanticidio no descubiertos. La creación de las ruedas de los expósitos fue direccionada con la intención de aminorar las altas tasas de mortalidad infantil pero también para combatir la ilegitimidad de estas criaturas cuando las madres solteras podían dejar a sus hijos de forma anónima, situación que no contrarrestó la incidencia de casos de infanticidio, ya que de acuerdo con Sheila de Castro Faria (2010, p. 84-85), este tipo de abandono se determinaba más por la situación de los padres que por la pobreza, pues, tanto en la rueda de los expósitos de Salvador como en la de Río de Janeiro, desde el siglo XVIII hasta la primera mitad del XIX, esas criaturas fueron indicadas precisamente como blancas, lo que deduce que aunque eran niños ilegítimos, sus padres también eran de origen social, económica y política dominante.

Ciertos autores han considerado los infanticidios un tipo de crimen privado, crímenes que se ejecutan en un ambiente íntimo, del hogar, donde las madres no son vistas. No sólo este tipo de asesinato es de carácter privado, sino que igualmente lo es el embarazo, que al ser secreto es lo que desencadena finalmente la muerte de la criatura, que también ocurre de forma clandestina. Las infanticidas actúan con mayor sigilo porque su estado dura aproximadamente nueve meses y muestran una evidencia física que a cada día se hace más notable; con ello, mienten, se sienten más presionadas y acorraladas ante el temor de ser descubiertas. Estas mujeres llegan a un punto donde se desembarazan de una prueba que las delata, lo que las hace proceder con angustia y rapidez para callar el gemido que las compromete, hallando, igualmente con desespero un lugar para borrar completamente la confirmación de su acto. Así, la particularidad de estos crímenes se evidencia por ser privados, pero, muchas veces, sus desfechos son expuestos en lugares públicos. Precisamente, las futuras madres daban a luz a sus pequeños recién nacidos generalmente en su habitación, en el piso, en la cama o en pie, o trataban de alejarse hasta un cuarto de los fondos de la casa con la intención de tener mayor intimidad, esta particularidad representó $29 \%$ del total de los casos investigados.

Las que tenían oportunidad de alejarse de su residencia, se dirigían a terrenos próximos, morros o siembras donde daban a luz con el silencio de la madrugada, y abandonaban o enterraban a sus hijos en este lugar, confiadas de que no serían descubiertas, figurando esta modalidad $19,4 \%$ de los casos encontrados. Cuatro 
de estas víctimas fueron encontradas en la calle 12,9\%; aparecían sus cuerpos a la mañana siguiente envueltos en periódicos o trapos viejos, otras cuatro criaturas nacieron y fueron dejadas en la letrina del baño donde sus progenitoras después de expulsarlas no les prestaban auxilio, dejándolas perecer por golpes en la cabeza o porque se ahogaban. En otros casos, la madre daba a luz dentro de su casa y dejaba o sepultaba al infante en el quintal (patio) de la misma, siendo que esta singularidad figuró en 9,7\% del total de los infanticidios.

\section{Los debates: la prensa, los médicos y juristas}

Para la prensa carioca, tratar los casos de infanticidio significó siempre un motivo para exponer la repulsa que la sociedad sentía al descubrir crímenes de este tipo. Las madres que asesinaban a sus hijos después de nacer, eran denunciadas principalmente como contrarias a su naturaleza, por tanto, antinaturales, deshumanas. Tales personajes eran expuestos como más cercanos a los animales, a las bestias irracionales que cometían actos salvajes sin piedad, sin sentimientos. De esta forma, los medios escritos dejaban completamente claro que sólo la madre amorosa era el ideal de mujer, ya que al ejercer este papel "se santificaba ante la humanidad, mostrando el verdadero motivo de su existencia”, en definitiva, la mujer completaba su rol social con el ejercicio de maternidad.

Por otra parte, en los casos de infanticidio, la comprobación de la vida extrauterina de la víctima es esencial, tanto para tipificar el delito, como para condenar a la madre. En los casos estudiados, inquéritos y procesos, se observa que las autoridades estaban conscientes de tal circunstancia y por ello, lo que inicialmente se hacía, además de los interrogatorios, era nombrar peritos que ejecutasen las respectivas revisiones en la víctima y en la denunciada. Cuando una mujer era descubierta infraganti o cuando se sospechaba de ella, el delegado emitía inmediatamente una orden para la práctica de un examen de parto supuesto, este procedimiento fue igualmente determinante para los juicios, ya que había que comprobar, desmentir o establecer una conexión real entre la víctima y la acusada, comprobándose que era su madre.

Una vez realizados los exámenes y tomadas las declaraciones de los testigos, el delegado encargado de la investigación presentaba un informe exponiendo los hechos más importantes del caso, así como su parecer para ser enviado el expediente al juez de algunas de las pretorías o varas criminales. Considerándose un caso procedente, tomando en cuenta las pruebas, testimonios e interrogatorio de la acusada y los resultados de la autopsia y parto supuesto, se procedía a la formación de culpa en la cual era revisto todo el sumario, allí también se calificaba e interrogaba formalmente al procesado, se pronunciaba la acusación por parte del Promotor Público y se establecía la defensa. No todos los expedientes analizados cuentan con toda esta información, algunos son más ricos que otros en detalles, sobre todo lo eran más, los casos que se publicitaban en la prensa y causaban revuelo y escándalo social. Precisamente, los incestos generaron este tipo de situación y los jueces eran inclementes en su percepción sobre el delito, mucho más del incesto que del propio infanticidio. 
Lamentablemente sólo los procesos contenían defensa y no todos las tenían por escrito, mucho menos fue posible saber cómo fue y cómo se generaban los debates durante el juicio porque no quedaron registrados dentro del expediente, a pesar de ello, a través de algunos de estos sumarios y en función de los argumentos usados por la acusada y la sentencia del caso, fue posible establecer algunas teorías usadas por la defensa. Estos principios fueron básicamente tres: falta de pruebas, pérdida de los sentidos y la deshonra. Fue común que los abogados defensores se valiesen de estas tres justificaciones para demostrar la inocencia de las "infanticidas".

\section{Las sentencias}

Llegar a una resolución en un caso de infanticidio fue un hecho realmente excepcional; crimen difícil de descubrir, probar y juzgar implicó un asunto complejo, largo y lleno de trabas que muchas veces no aparece completo o decanta con el cierre de la investigación. Considerando que este estudio comprende el análisis de inquéritos, investigaciones que se llevaron a cabo para apurar pruebas contra la acusada, a veces dejaron un sabor fragmentado de querer saber más o pensar que se pudo hacer más dentro del mismo, ya que $80 \%$ de los 15 inquéritos examinados fueron archivados por falta de pruebas y sólo un caso se cerró por demostrarse que la denunciada no tenía responsabilidad criminal. La ausencia de pruebas ocurría básicamente cuando no se podía determinar la vida extrauterina de la víctima, su causa de muerte o porque no se hallaba algún culpable, esto último sucedía, sobre todo, cuando aparecían fetos en la vía pública. De igual forma, hubo fallas en las investigaciones, principalmente en las autopsias realizadas en los recién nacidos porque a veces los peritos eran vacilantes y hasta contradictorios en sus respuestas, otros, estuvieron imposibilitados de comprobar la respiración extrauterina y causa de muerte de las criaturas.

Ya cuando un inquérito reunía, de acuerdo al Ministerio Público y al juez los fundamentos suficientes para proseguir a una acusación formal, se entablaba un sumario que llevaría a un juicio y posterior sentencia. Los juicios fueron relativamente rápidos, esto dependió de la publicidad del caso, algunos de ellos se realizaban en las Cámaras Municipales donde se nombraba con anticipación un jurado "popular" compuesto por 47 personas de las cuales se sorteaban 12 que conformarían el "jurado de sentencia” que junto con el Promotor Público y los abogados de la defensa debatían sobre el proceso. Estos juicios eran de carácter público, lo que llevó en los crímenes resonados bastante multitud ansiosa por conocer el destino de la "infanticida". De esta forma, los procesos analizados, muestran que $18 \%$ de estos enjuiciados fueron condenados, mientras que $50 \%$ de las acusadas, específicamente las mujeres, fueron absueltas. Al mismo tiempo, se maneja una variable importante y es que $25 \%$ de estos casos desafortunadamente están incompletos, lo que deja un vacío considerable al momento de razonar las sentencias. Con todo, como se aprecia, las condenaciones fueron raras, ya que en sólo tres casos se castigó al procesado, lo que sucedió particularmente cuando el proceso incluyó además de infanticidio, otra transgresión como abandono o incesto. 
Las madres que fueron absueltas por el "jurado de sentencia”, de ese 50\%, la mitad, $25 \%$ lo fueron por falta de pruebas y otro $25 \%$ por alienación mental. En el primero de los casos, los mismos estuvieron determinados por la carencia de elementos que comprometieran directamente a la acusada, básicamente esto se dio cuando no existía cuerpo de delito, dificultad para determinar la respiración extrauterina de la víctima, conexión entre la enjuiciada y la criatura y deficiencia en la recolección de pruebas durante el proceso. Las "infanticidas" absueltas por alienación mental fueron aquellas acusadas cuyo proceso además de ser bastante publicitado, también mostraban pruebas contundentes de su culpabilidad. ¿Cómo absolver a una madre que asesinaba a su hijo recién nacido cuando había indicios suficientes en su contra? y ¿por qué mataban estas madres? Para los "jurados de sentencia”, hombres de cierta posición y con valores morales bien definidos, las infanticidas eran mujeres que se negaban a ejercer su glorioso papel de madres. Para los médicos y juristas, era difícil explicar la existencia de tales asesinas; ¿rechazaban ellas la maternidad o eran anormales? ¡Claro que eran anormales! y entre más monstruoso fuese su crimen, mejor explicación tenía el mismo.

En este sentido, ciertos autores han establecido una diferencia entre las infanticidas que han sido absueltas apelando a un sentimiento de deshonra y las que su inocencia se dio en función de una alienación mental. De acuerdo a la experiencia tratada en varios casos de infanticidio, no sólo en Río de Janeiro, sino también en Venezuela, la honra femenina fue un sentimiento supervalorado que les sirvió a las acusadas como un atenuante perfecto de un comportamiento considerado irracional. Para los juristas y médicos, la discusión de este tipo de crímenes los dividía entre la falta de instinto maternal y la deshonra de las infanticidas, ahora, a partir de las nuevas teorías de degeneración, las mujeres acusadas de asesinar a sus hijos recién nacidos no encuadraban en la normalización de la sociedad, no eran higiénicas, no eran normales, ya que para ellos no se trataba sólo de explicar a simples homicidas, eran infanticidas, la antítesis de la madre como generadora de la base social, la familia, la sociedad, la civilización. El honor estuvo en estos casos íntimamente ligado a ese descontrol del que hablaban los médicos, tratándose más adelante como estado puerperal. Para ser "asesinas por pasión", debía concurrir en la acusada una aflicción profunda que desencadenase su estado patológico de pérdida de los sentidos, de alienación, y ese sentimiento fue la vergüenza, la deshonra y el agobio extremo que se generaba en una madre que temía profundamente el escándalo y la condena social.

\section{Consideraciones finales}

Es indudable que los infanticidios son crímenes ambivalentes porque son delitos que se balancean entre la indignación de la pérdida de una vida recién nacida y la tragedia de una madre que intenta escapar de la exposición social. Fueron de igual forma, prácticas comunes de las que todos conocían, pero de las que sólo se hablaba cuando la luz del escándalo los exponía. Partiendo de ello, también es evidente la íntima relación que existe entre la honra y los infanticidios, precisamente porque son delitos que se tipifican, se juzgan y se condenan atendiendo a una conducta sexual 
honrada en la madre, que la mayoría de las legislaciones reconoce como atenuante. Por tanto, para la ley, no se trata de cualquier comportamiento sexual, ni de cualquier mujer; para que esta circunstancia sea válida, la acusada debe haber tenido en su vida anterior fama de honrada; observancia que sólo viene dada a través de la reputación y la consideración social que los demás tienen de ella, y por eso, inmiscuye mucho de las apariencias. En este sentido, el honor sirvió como un valor que estableció categorías basadas en distinciones de raza, sexo y color, pues no todos los individuos eran merecedores de tal condición. Las mujeres, por ejemplo, no sólo ostentaban un honor basado en su conducta moral y sexual, sino que lo preservaban llevando a sus espaldas las cargas del honor familiar, que a su vez fue defendido en espacios públicos por sus pares masculinos.

Esta concepción tan tradicional sobre la honra, entró en conflicto y comenzó a ser discutida principalmente a partir del análisis que, sobre todo los juristas tenían acerca de los peligros que la modernidad podía causar en las mujeres de la sociedad carioca. La "libertad" que algunas mostraban al frecuentar espacios públicos, al no respetar el recato, la castidad, la virginidad o no permanecer vigiladas causaba contradicciones sobre el ideal de mujer que se tenía. Muchas, particularmente aquellas que necesitaban salir, transitar o trabajar fueron vistas como "desviantes", "desclasificadas", mujeres que representaban un peligro al orden y a la civilización. El concepto de honra, entra así en contrariedad, pues para estos especialistas resultaba complejo entender tales realidades, mucho más cuando algunas de estas mujeres llegaban a la justicia por crímenes de tipo sexual.

Cuando las "infanticidas" entraban en escena comenzaban los debates. Estas disyuntivas se multiplicaban desde la prensa al noticiar con horror casos de este tipo y al tachar a sus responsables como madres desnaturalizadas, madres monstro, madres fieras y anormales, hasta los juicios que éstas enfrentaban. Para los jueces y médicos estas mujeres eran la antítesis del ideal de madre, principalmente porque no nacía en ellas el sentimiento maternal que era afín a su naturaleza y porque era complicado aceptar su existencia. Ante ello, estos especialistas se valieron de explicaciones para justificar sus actos irracionales, siendo que, precisamente esas acciones entre más bárbaras y bestiales fuesen, mejores interpretaciones tenían. Así, las madres asesinas eran mujeres que se descontrolaban al verse afligidas ante una situación desesperante como lo era un embarazo ilegítimo que las llevaba a la deshonra, condiciones que fueron encuadradas dentro del estado puerperal que suscitaba en la madre un sentimiento de exaltación, de desespero incontrolable que las llevaba a convertirse en asesinas por pasión.

Finalmente, los infanticidios y sus protagonistas comenzaron a ser centro de controversias que apuntaban a cierta indulgencia. Los juristas y médicos podían reconocer especialmente en aquellas, mujeres frágiles, ignorantes que cedían ante las promesas ilusorias de un amante que las seducía, engañaba y abandonaba. Ya deshonradas, apelaban a cualquier recurso para evitar su condena social y en esto se evidencia que la concepción tradicional de honra que super valorizaba la virginidad configuró el principio más transcendental dentro de este tipo de crímenes. Apelando 
de esta forma a un sentimiento de vergüenza y repudio, las madres que asesinaban a sus hijos recién nacidos despertaron durante el siglo XIX y principios del XX en Río de Janeiro la benevolencia de sus acusadores quienes admitían en su deshonra un motivo suficientemente fuerte para matar.

\section{Referencias}

\section{Fuentes Primarias}

\section{Arquivo Nacional (AN), Río de Janeiro (Brasil)}

BR.AN.RIO. Relação do Rio de Janeiro 84. Apelação Criminal ACR. Infanticídio. 18411843. \# 126. Caixa 110. Angélica Maria de Jesus.

BR.AN.RIO. Relação do Rio de Janeiro 84. Apelação Criminal ACR. Infanticídio. 18891890. \# 994. Caixa 105. Galeria C. Tertuliano Cardozo Leal.

BR.AN.RIO.OI.O.PCR.3075 / BR.AN.RIO.OR.O.IQP.687 / BR.AN.RIO.OI.O.IQP.2872 / BVO. RMI.0153. \#1214 / BR.AN.RIO.T8.O.IQP.1773 / BR.AN.RIO.7H.O.IQP.671/ BR.AN.RIO.7C. Pretoria de São Cristóvão. \#870. Mç. 320. GI. A / BR.AN.RIO.7H.O.IQP.821 / BR.AN. RIO.CA.CT4.O.376 / BR.AN.RIO.T8.O.PCR.2480 / BR.AN.RIO.7E.O.IQP.1626 / BR.AN. RIO.CS.O.IQP.237 / BR.AN.RIO.T8.O.IQP.2697 / BR.AN.RIO.CA.CT4.O.492 / BR.AN. RIO.CS.O.IQP.488 / BR.AN.RIO.MW.O.IQP.2634 / BR.AN.RIO.CR.O.IQP.466 / BR.AN. RIO.6Z.O.IQP.105 / BR.AN.RIO.CR.O.IQP.674 / BR.AN.RIO.CS.O.PCR.2059 / BR.AN. RIO.6Z.O.IQP.16784 / BR.AN.RIO.6Z.O.IQP.19277

\section{Museu do Tribunal da Justiça do Rio de Janeiro}

Museu do Tribunal da Justiça. Tribunal do Júri Cabo Frio. 18898. RG: 18107. Cx: 1876. Apollinaria Rosa. 1890.

Museu do Tribunal da Justiça. 1 Cartório do Júri do Distrito Federal. 14033. RG:13242. Cx. 1403. Alice do Espirito Santo. 1902.

Museu do Tribunal da Justiça. 1 Cartório do Júri do Distrito Federal. 14034. RG: 13234. Cx. 1403. Laura Sobral. 1902.

Museu do Tribunal da Justiça. $1^{\circ}$ Cartório do Júri do Distrito Federal. RG: 13244. Emília Faustina. 1903.

Museu do Tribunal da Justiça. $1^{\circ}$ Cartório do Júri do Distrito Federal. RG: 13245. Olivia Nogueira da Gama. 1904.

Museu do Tribunal da Justiça. $4^{\circ}$ Cartório do Júri do Distrito Federal. 5173. RG: 4382. Cx. 577. Joaquina Gonçalves. 1910.

Museu do Tribunal da Justiça. Juízo de Direito. 18991. RG: 18200. Cx. 1884. Maria Piedade da Conceição. 1925. 


\section{Bibliografía}

BRETAS, Marcos Luiz. Ordem na Cidade: o exercício cotidiano da autoridade policial no Rio de Janeiro, 1907-1930. Tradução de Alberto Lopes. Rio de Janeiro: Rocco, 1997.

CAULFIELD, Sueann. Em defesa da honra: moralidade, modernidade, e nação no Rio de Janeiro (1918-1940). Campinas: Editora da UNICAMP, Centro de Pesquisa em História Social da Cultura, 2000.

CHALHOUB, Sidney. Trabalho, lar e botequim: o cotidiano dos trabalhadores no Rio de Janeiro da belle époque. 2a Ed. Campinas: Editora da UNICAMP, 2001.

ENGEL, Magali. Meretrizes e doutores: saber médico e prostituição no Rio de Janeiro (1840-1890). São Paulo: Brasiliense, 2004.

ESTEVES, Martha de Abreu. Meninas perdidas: os populares e o cotidiano no Rio de Janeiro da Belle Époque. Rio de Janeiro: Paz e Terra, 1989.

FÉBRES CORDERO, Héctor. Curso de Derecho Penal. Parte Especial. Delitos contra las personas. 2ª Edición. Mérida: Talleres Gráficos Universitarios, 1962.

GARCÍA MAAÑON, Ernesto y Alejandro BASILE. Aborto e Infanticidio. Aspectos Jurídicos y Médicos legales. Buenos Aires: Editorial Universidad, 1990.

LOPES FILHO, João Goncalves. Do infanticídio. Tesis doctoral, Facultad de Medicina do Rio de Janeiro. Universidad Federal de Río de Janeiro. Brasil, 1894.

MENDOZA TROCONIS, José Rafael. “Infanticidio por Móvil de Honor”. En: Revista de Derecho Penal. Ediar Soc. Anien Editores. Sucesores de Compañía Argentina de Editores S.R.L. Primera Sección. Buenos Aires, Argentina. Año IV, \# 1, 1948. p. 143 - 155.

NEVES, Antônio Joze Pereiras das. Sciencias acessórias (Do infanticidio). Sciencias cirúrgicas (Da prenhez ovárica). Sciencias médicas (Diagnostico diferencial do ventrículo direito do coração e do esquerdo). Indicações e contraindicações da sangria geral em ambos casos). Tesis doctoral, Facultad de Medicina do Rio de Janeiro. Universidad Federal de Río de Janeiro. Brasil, 1839.

PACHECO, Augusto Militão. Do Infanticidio. Tesis doctoral, Facultad de Medicina do Rio de Janeiro. Universidad Federal de Río de Janeiro. Brasil, 1893.

OSORIO, Manuel. Diccionario de Ciencias Jurídicas, Políticas y Sociales. Editorial Heliasta, S.R.L. Buenos Aires, 1981.

RAMíREZ MÉNDEZ, Luís A. De la Piedad a la Riqueza. Convento de Santa Clara de Mérida, 1651 - 1874. Mérida: Archivo Arquidiocesano de Mérida. Fuentes para la Historia Eclesiástica de Venezuela, 2005.

RIBEIRO, Gláucio Vasconcelos. Infanticídio: crime típico; figura autônoma; concurso de agentes. São Paulo: Pillares, 2004.

RINALDI, Alessandra de Andrade. Sexualização do crime no Brasil: um estudo sobre a criminalidade feminina no contexto das relações amorosas (1890-1940). Rio de Janeiro: Mauad X: FAPERJ, 2015. 
FARIA, Sheila Castro de. "A propósito das origens dos enjeitados no período escravista". Em: Uma história social do abandono de crianças. De Portugal ao Brasil: séculos $X$ VIII-XX. Renato Pinto Venâncio (Org.). São Paulo: Alameda/ Editora PUC Minas, 2010. p. 81-98.

SOIHET, Rachel. "Mulheres pobres e violência no Brasil Urbano". Em: Histórias das mulheres no Brasil. Mary del Priore (Org.). 10a. ed. São Paulo: Contexto, 2015. p. 362-400.

TWINAM, Ann. Vidas Públicas, Secretos Privados. Género, Honor y Sexualidad en la Hispanoamérica Colonial. Primera Edición. Buenos Aires: Fondo de Cultura Económica. (Traducción de Cecilia Inés Restrepo), 2009.

\section{Notas}

1 En el caso específico de las legislaciones analizadas para el periodo en estudio, a partir del Código Criminal del Imperio de Brasil de 1830 el infanticidio comienza a ser criminalizado como una figura excepcional en su Art. 198: "Se a propia mãi matar o filho recem-nascido para occultar a sua desonra. Penas- de prisão com trabalho por um a três anos". Por su parte, el Código Penal de 1890 destacó el infanticidio como una figura delictuosa "sui generis" sin limitar el privilegio Honoris Causa, estableciéndolo en su Art. 298: "Matar recemnascido, isto é, infante, nos sete primeiros dias de seu nascimento, quer empregando meios directos e activos, quer recusando a victima os cuidados necessários à manutenção da vida e a impedir sua morte: pena de prisão cellular por seis a vinte e quatro annos. Paragrapho único. Se o crime for perpetrado pela mãe para occultar a deshonra propia: Pena de prisão cellular por três a nove anos" (RIBEIRO, 2004, p. 28-37).

$\mathbf{2}$ Los vacíos dejados por este código hicieron que tuviera varias tentativas para sustituirlo, se exhiben algunas de esas propuestas: La primera de ellas es el Proyecto de Galdino Siqueira (1913) quien no consideró el infanticidio como un crimen independiente y sí como tipo de homicidio privilegiado. La segunda propuesta fue la del Proyecto de Sá de Pereira (1928), quien contrariamente a Galdino, contemplaba el infanticidio como una figura autónoma y al mismo tiempo incluyó otros elementos relacionados como el tiempo sobre el cual podía ocurrir el crimen (durante el parto o bajo la influencia del estado puerperal). La tercera propuesta estuvo relacionada con el Proyecto de Alcântara Machado (1940), quien rescata las ideas planteadas en el Código Criminal de 1830, estipulando así el criterio Honoris Causa. Igualmente, hizo extensiva la motivación a los parientes ascendientes y descendientes de la madre, así como al marido (IBIDEM, p. 18-28). Finalmente, el Código Penal de 1940, determinó el criterio físico-psicológico, excluyendo así la motivación de la deshonra. 3 RUGGIERO, Kristin. "Maternity, and the Disciplining of Women: Infanticide in Late Nineteenth-Century Buenos Aires”. En: Hispanic American Historical Review. Vol. 72, \# 3. Agosto, 1992. p. 353-373.

4 BUENAVENTURA GÓMEZ, Laura A., Malas amistades: infanticidios y relaciones ilícitas en la Provincia de Antioquia (Nueva Granada) 1765-1803. Bogotá: Editorial Universidad del Rosario, 2017.

5 NUÑEZ CETINA, Saydi. "Reforma social, honor y justicia: infanticidio y aborto en la Ciudad de México, 19201940". En: Signos Históricos. \#28, Julio-diciembre, 2012. p. 68-113.

6 PRADA M., Jhoana G. El Infanticidio: perspectiva comparada y aportes bibliográficos de Europa y América Latina. Tesis de Máster. Facultad de Letras. Universidad de Murcia. Directora: Lucía Provencio Garrigós. Murcia, España, 2010.

7 TILLIER, Annick. Des Criminelles au Village Femmes Infanticides en Bretagne (1825-1865). Presses Universitaires de Rennes. Collection Histoire, 2001.

8 PROSPERI, Adriano. Dar a alma. História de um infanticídio. São Paulo: Companhia das Letras, 2010.

9 GUIMARÃES SÁ, Isabel. "Abandono de Crianças, Infanticídio e Aborto na Sociedade Portuguesa Tradicional através das Fontes Jurídicas”. En: Penélope: Revista de História e Ciências Sociais. \# 8, 1992. p. 75-90. 
10 PEDRO, Joana Maria. Práticas proibidas: práticas costumeiras de aborto e infanticídio no século XX. Florianópolis: Cidade Futura, 2003; NASCIMENTO, Alcileide Cabral do. A sorte dos enjeitados: o combate ao infanticídio e a institucionaloçao da assitencia as crianças abandonadas no Recife (1789-1832). São Paulo: Annablume: FINEP, 2008; ROHDEN, Fabíola. A arte de enganar a natureza: contracepção, aborto e infanticídio no início do século XX. Rio de Janeiro: Editora FIOCRUZ, 2003; WADI, Yonissa Marmitt. A história de Pierina: subjetividade, crime e loucura. Uberlândia: EDUFU, 2009.

Jhoana PRADA MERCHÁN é venezuelana. Licenciada em História pela Universidade de Los Andes (ULA, Venezuela) e Licenciada em Educação Menção Ciências Sociais pela mesma universidade. Mestre em História Comparada das Relações Sociais, Familiares e de Gênero em Europa e América Latina pela Universidade de Murcia (UMU, Espanha) e Doutora em História Social pela Universiadade Federal do Rio de Janeiro (UFRJ), Brasil). Palestrante no III Congresso Sul-americano de História. Vinculada ao Grupo de Investigação Conversações de Mulheres e Gênero (UMU) e membro do Conselho de redação da Revista Procesos Históricos-Revista de História y Ciencias Sociales de la Universidad de Los Andes (ULA). Atualmente desenvolve trabalhos de pesquisa na área de História Social, História de Gênero e História da Mulher. Especialista e com várias publicações referentes a tópicos como honra, infanticídio, violência, estupro, família, casamento e situação social da mulher em Venezuela e Rio de Janeiro nos séculos XIX e inícios do XX.

Recebido em: 09 janeiro 2019

Aprovado em: 28 outubro 2019 